\title{
Evaluation of a high-resolution regional climate simulation over Greenland
}

Filip Lefebre ${ }^{1,2}(*), X_{\text {avier Fettweis }}{ }^{1}$, Hubert Gallee ${ }^{3}$, Jean-Pascal van ypersele ${ }^{1}$, Philippe Marbaix ${ }^{1}$, Wouter Greuell ${ }^{4}$, Pierluigi Calanca ${ }^{5}$

${ }^{1}$ Institut d'Astronomie et de Géophysique G. Lemaître, Université catholique de Louvain, Louvain-la-Neuve, Belgium

9 Integral Environmental Studies, Vito (Flemish Institute for Technological Research), Mol, Belgium

${ }^{3}$ Laboratoire de Glaciologie et de Géophysique de l'environnement, Grenoble,

12 France

${ }^{4}$ Institute for Marine and Atmospheric Research, Utrecht University, Utrecht, The Netherlands

$15{ }^{5}$ Swiss Federal Research Station for Agroecology and Agriculture, Zurich, Switzerland

18 (*) Corresponding author address: Integral Environmental Studies, Vito (Flemish Institute for Technological Research), Boeretang 200, B-2400 Mol, Belgium. Tel: + 32143368 47, Email: Filip.Lefebre@vito.be

\section{Abstract}

A simulation of the 1991 summer has been performed over south Greenland with a coupled 
atmosphere-snow regional climate model forced by the ECMWF re-analysis. The simulation is

24 evaluated with in-situ coastal and ice sheet atmospheric and glaciological observations. Modelled air temperature, specific humidity, wind speed and radiative fluxes are in good agreement with the available observations although uncertainties in the radiative transfer scheme need further

27 investigation to improve the model performance.

In the sub-surface snow-ice model, surface albedo is calculated from the simulated snow grain shape and size, snow depth, meltwater accumulation, cloudiness and ice albedo. The use of the

30 snow metamorphism processes allows a realistic modelling of the temporal variations in the surface albedo during both melting periods and accumulation events. Concerning the surface albedo, the main finding is that an accurate albedo simulation during the melting season strongly depends on a

33 proper initialization of the surface conditions which mainly results from winter accumulation processes. Furthermore, in a sensitivity experiment with a constant 0.8 albedo over the whole ice sheet, the average amount of melt decreased by more than $60 \%$ which highlights the importance of

36 a correctly simulated surface albedo.

The use of this coupled atmosphere-snow regional climate model opens new perspectives in the study of the Greenland surface mass balance due to the represented feedback between the surface

39 climate and the surface albedo which is the most sensitive parameter in energy-balance based ablation calculations. 


\section{1. Introduction}

One of the unknowns of the projected global warming due to anthropogenic forcing is the expected mean sea-level rise. The contribution of each individual

54 component, i.e., the ocean's thermal expansion as well as the mass budgets of Antarctica, Greenland and the continental small ice caps and glaciers, must be known (Houghton et al., 2001).

Experimental campaigns such as EGIG 1959 and 1967 (Ambach, 1988), ETHCamp (Ohmura et al., 1992), GIMEX (Oerlemans and Vugts, 1993), KABEG

60 (Heinemann, 1999) and PARCA (Thomas et al., 2001) give local instantaneous information of the surface mass balance but it is hazardous to estimate the total Greenland surface mass balance from these measurements because of their limited 63 spatial and/or temporal resolution.

In contrast with these measurements, numerical models offer the possibility to 66 evaluate past, present and future changes in the Greenland mass balance. Numerical models also allow the separation and quantification of each individual process contributing to the ice sheet's mass balance.

Van de Wal and Oerlemans (1994) were the first to calculate the Greenland surface mass balance by means of an energy balance model but made use of

72 simple parameterizations for the incoming short and longwave radiation fluxes. Also the turbulent energy fluxes were based on simple linear relationships and no distinction between the sensible and latent heat flux was made.

Global circulation models (GCMs) also explicitly calculate the surface energy balance and are suited for climate change experiments. However, their major 78 weakness is their rather coarse horizontal resolution. They are unable to represent for example the Greenland ablation zone which ranges from a few kilometers in the south-east to $100 \mathrm{~km}$ at its largest in west-Greenland. Also the ice sheet

81 topography is not exactly represented and leads to important errors in the amount of cloudiness, precipitation and ablation. Ohmura et al. (1996) showed the high sensitivity to horizontal resolution for the simulated precipitation field.

84 Furthermore, Hanna and Valdes (2001) analyzed in detail the ECMWF (European Centre for Medium-Range Weather Forecasts) ERA-15 re-analysis surface climate 
data for the period 1979 to 1998 and found that surface albedo and cloud errors

87 need to be rectified if the analysis are used effectively to drive energy balance models for Greenland ablation calculations.

Another problem is that most GCMs do not include physically based surface

90 albedo parameterizations nor they include ice sheet specific processes such as refreezing of meltwater which is of major importance in the Greenland higher ablation and percolation zone (Pfeffer et al., 1991). It is of capital importance to

93 correctly simulate the surface albedo since a small albedo error may induce important errors in the simulated surface net radiation balance which is the major source of energy to heat and melt snow and ice. Nolin and Stroeve (1997) showed

96 that even in areas that experience little or no melt, important surface albedo decreases of 10-20\% are common. These reductions are found to be related to slow increases of snow grain size.

99

A way to refine and to correct GCM predictions of the Greenland surface mass balance is to nest a regional climate model (RCM) within GCM generated 102 atmospheric fields. The RCM can be run at a higher resolution, thereby representing more correctly the topography of the steep Greenland ice sheet margins which improves the simulated atmospheric fields (Georgi et al., 1999)

105 that force the surface mass balance.

Cassano et al. (2001) presented an evaluation of an annual atmospheric 108 simulation over Greenland with the Polar MM5 model. It should be stressed that their simulation was compiled from a series of short duration (48 hour), forecast mode, simulations. From these 48 hour simulations, only the last 24 hours are

111 used. In the Polar MM5, the Greenland ice sheet surface is represented by a diffusive multi-layer surface model with fixed surface properties. In particular the use of a fixed surface albedo $(0.80)$ can lead to large errors in the simulated net

114 radiation budget over melting surfaces during the summer .

In this paper, we will present an evaluation of a coupled model run in which a 117 high-resolution $(20 \mathrm{~km})$ atmospheric regional climate model is coupled with a physically based snow-ice model. Specific surface processes such as melting, percolation and refreezing of meltwater as well as the snow grain metamorphism

120 processes and the closely related snow albedo variations are taken into account. The coupled regional climate model (RCM) will be applied over south Greenland 
during the 1991 ablation season. It is nested into the ECMWF ERA-15 re-analysis

123 with a single initialisation procedure at the start of the simulation. In a first attempt, we will focus on the summer season and the accuracy of the surface albedo simulation. The use of re-analyzed forcing fields instead of present climate

126 GCM output minimizes the errors that could be due to wrong input data. It also enables us to compare the model output with in-situ observations. This work is part of a long-term research project to better estimate the Greenland climate and

129 surface mass balance (Gallée et al., 1995; Gallée and Duynkerke, 1997; Lefebre, 2003). In the next section, a brief description of the coupled atmosphere-snow RCM is given. Afterwards, the simulation is described and evaluated through 132 comparison with near-surface atmospheric and mass balance measurements. In particular, the simulated surface albedo will be compared with observations from 3 locations on the ice sheet. The reference experiment will also be compared with

135 a sensitivity experiment in which the surface albedo has been kept constant at 0.8 over the ice sheet. 


\section{2. Coupled atmosphere-snow regional climate model}

\subsection{General description}

141 The coupled atmosphere-snow regional climate model used is MAR (Modèle Atmosphérique Régional). The atmospheric part of MAR is fully described in Gallée and Schayes (1994) and Gallée (1995). MAR is a hydrostatic primitive

144 equation model in which the vertical coordinate is the normalized pressure

$$
\sigma=\frac{p-p_{t}}{p_{s}-p_{t}}
$$

$p, p_{t}$ and $p_{s}$ being the pressure, the constant model top pressure and the surface

147 pressure, respectively. MAR was originally developed for process studies in the polar regions but is now besides Antarctica (Naithani et al., 2002) also applied over Europe for nested climatic studies (Marbaix, 2000; Brasseur et al., 2002).

150 The lateral boundary nudging treatment consists of a buffer zone (width of 5 points) involving "Newtonian" and "diffusive" relaxation terms. Lateral boundary conditions are updated each 6 hours and a linear interpolation is made in between

153 (Davies, 1983; Marbaix et al., 2003).

Sea surface temperatures are prescribed from ECMWF re-analysis. Sea ice is not modelled explicitly but its distribution is deduced from ECMWF sea surface

156 temperatures. Inside the ECMWF re-analysis system, satellite observations are used to define the actual sea-ice distribution (Nomura, 1995). Open water and sea ice have an albedo of 0.07 and 0.55 , respectively. A band of tundra points borders

159 the inland ice sheet. In case of a snow-free tundra surface, the force-restore surface model of Deardorff (1978) with a soil thermal conductivity of $0.65 \mathrm{~W} \mathrm{~m}^{-1} \mathrm{~K}^{-1}$ and an albedo of 0.20 is used to predict the tundra surface temperature. When snow 162 covers the tundra soil, the snow model is used (see below).

\subsection{Snow and ice model}

165 The snow model is described in details in Gallée and Duynkerke (1997) and Gallée et al. (2001). It is validated for a site on the Greenland ice sheet (ETHCamp, west Greenland, 1150 m a.s.1.) in Lefebre et al. (2003). 
168 In the multi-layered thermodynamic one-dimensional snow model, snow metamorphism processes are represented by the CROCUS snow metamorphism laws (Brun et al., 1992). The latter allow, in combination with the detailed

171 meltwater budget representation, to represent the evolution of the snow grain characteristics (shape and size) and its albedo. Afterwards, the surface albedo is calculated from (1) the snow albedo, (2) the depth of the snow pack upon the ice

174 or the tundra, (3) the accumulated meltwater (over the ice sheet only) and (4) the albedo of the underlying ice or tundra.

177 During off-line (forced with observations) simulations at ETH-Camp (west Greenland), the simulated surface albedo and the simulated surface mass balance were found to be in good agreement with the observations (Lefebre et al., 2003).

In the present article, the same snow model configuration as the one used for the validation is used with two modifications. The first change deals with the

183 influence of atmospheric cloudiness on the surface albedo. Clouds tend to increase the proportion of the visible part of the solar radiation spectrum, modifying the incident solar radiation spectrum. This leads to a small increase of about 0.05 in

186 the broadband surface albedo (Key et al., 2001). The coupling between the atmospheric part of MAR and its snow model uses a fixed solar radiation spectrum with the simulated broadband solar incident radiation flux. Therefore an

189 additional term in the surface albedo calculation has been added as in Greuell and Konzelmann (1994) to account for the small increase in surface albedo (up to $0.05)$ due to clouds.

Secondly, compared to the validated version, the density and grain size and shape for fresh snow are not calculated with the original CROCUS fresh snowfall 195 parameters (dendricity, sphericity and density). In Lefebre et al. (2003), the original CROCUS fresh snow fall parameters proved to be adequate for ETHCamp summer snowfalls. This is due to the location of the site, which is rather 198 close $(40 \mathrm{~km})$ to the ice sheet margin, and the occurrence of abundant surface melt. The latter rapidly transforms freshly-fallen dendritic snow grains into round snow grains. In the present simulations, the fresh snow parameters ought to be

201 valid not only in the Greenland ablation zone but also for the rest of the Greenland ice sheet which also includes the ice sheet dry snow zone where no melt occurs. Therefore, fresh snow is characterized by a snow density of $300 \mathrm{~kg} \mathrm{~m}^{-3}$ and by 
204 round, $0.3 \mathrm{~mm}$ large spherical snow grains in agreement with surface snow observations in the dry snow zone (Morris et al., 1997).

\section{2.3. Model setup}

The simulation starts the first of May 1991 and lasts until the end of August, i.e. 123 days which corresponds with the major melting period over the Greenland ice

210 sheet. Mass balance observations at ETH-Camp during the 1991 field season revealed that the melting season stopped around mid-August.

\section{Figure 1}

Figure 1: The prescribed distribution of MAR mass balance zones on the Greenland ice sheet and the major locations referred to in the text. From black to light grey over the ice sheet: ice sheet

216 ablation zone, percolation zone and dry snow zone. The model ablation zone delineation is specified and taken from Reeh (1991). (Right) MAR surface height (isolines) and the difference (shades of grey) between MAR and ECMWF model surface height.

The integration domain encompasses the southern part of Greenland and its neighbouring waters (Figure 1). MAR fine-grid topography and soil type for

222 Greenland are taken from the Eckholm (1996) Greenland topography and land masks. The size of the domain is $2000 \mathrm{~km}$ by $2000 \mathrm{~km}$ with a high horizontal resolution of $20 \mathrm{~km}$ in order to represent the ice sheet ablation zone and the

225 succession of the different mass balance zones. Denby (2001) examined the sensitivity of turbulent fluxes and katabatic wind speed maximums to the horizontal resolution. A resolution of $20 \mathrm{~km}$ proved to be a good compromise.

228 Wind speed maxima only slightly increased at $10 \mathrm{~km}$ resolution. Therefore, a resolution of $20 \mathrm{~km}$ enables a correct representation of the katabatic winds and henceforth of the turbulent heat fluxes due to the mixing of warmer air from above

231 with the cold air in the vicinity of the ice sheet surface. Although a higher resolution would still be recommendable for some very steep locations (for example in east Greenland), previous regional atmospheric simulations with

234 complete 3-dimensional models (e.g. Cassano et al. 2001; Bromwich et al. 2001b) never used resolutions finer than $40 \mathrm{~km}$. Computing time is still a limiting factor in regional climatic simulations.

Strong vertical gradients of wind speed and temperature are found close to the 
surface of the Greenland ice sheet. Therefore the lowest atmospheric model level

240 has been put at $2 \mathrm{~m}$ above the surface. The next 4 levels are situated at 4, 8, 16, and $32 \mathrm{~m}$ above the surface, respectively. The model has been initialized once. The lateral boundaries are updated every 6 hours with the ECMWF ERA-15 re243 analysis for temperature, specific humidity, wind components and surface pressure. Linear interpolation in time is made in between.

\section{2.4. Initialization}

MAR atmospheric wind components, air temperature and specific humidity as well as the surface temperatures and deep-soil tundra temperatures are initialized

249 from the ECMWF ERA-15 re-analysis. Ideally, we should spin-up the snow model separately during a long-term period in order to obtain equilibrated snow and ice initial temperature and density fields. For our simulations, we have in a

252 first attempt, prescribed these initial fields. In particular over the ice sheet, the snow and ice initial temperatures are initialized by linear interpollation between the ECMWF ERA-15 surface temperature and the climatological deep snow and 255 ice temperature $\left(T_{a n n}\right)$. The latter was taken from Reeh (1991) who derived a parameterization based on long-term ice sheet temperature records for the 19511961 period. This parameterization, or with slightly different parameters, is also

258 used in thermodynamic ice sheet models of the Greenland ice sheet as an approximation of the annual average surface temperature (see e.g. Huybrechts et al. (1991); Ritz et al. (1997)):

$261 T_{a n n}\left(\right.$ in $\left.^{\circ} \mathrm{C}\right)=48.38-0.007924 * E-0.7512 * L$

with $E$ the surface elevation (m) and $L$ the latitude $\left({ }^{\circ} \mathrm{N}\right)$.

264 The dry snow zone has been delineated as the area with an annual mean temperature of less than $-25^{\circ} \mathrm{C}$ (Benson, 1962). The model ablation zone delineation is taken from Reeh (1991). In the model ablation zone, the 1990-1991

267 winter precipitated snow from Bromwich et al. (2001a) is laid on top of a $20 \mathrm{~m}$ thick prescribed ice pack. By lack of reliable data, we neglect the impact of snow drift, evaporation and sublimation. This can eventually lead to an overestimation

270 of more than $10 \%$ of the snow pack height according Box and Steffen (2001). A typical surface snow density of $300 \mathrm{~kg} \mathrm{~m}^{-3}$ has been chosen (Morris et al., 1997). In the area between the ablation zone and the dry snow zone (denoted percolation 
273 zone) the snow density has been put equal to $500 \mathrm{~kg} \mathrm{~m}^{-3}$ for the lowest $20 \mathrm{~m}$ of the snow pack. On top of it, as in the ablation zone, the Bromwich et al. (2001a) 1990-1991 winter snow fall has been added with a density of $300 \mathrm{~kg} \mathrm{~m}^{-3}$. In the

276 dry snow zone, the snow density between the bottom of the snow model at $20 \mathrm{~m}$ depth and the surface snow has been calculated with the empirical density-depth relation from Schytt (1958):

$$
\rho=\rho_{\mathrm{i}}-\left(\rho_{\mathrm{i}}-\rho_{\mathrm{s}}\right) * \exp \left(-C^{*} z\right)
$$

where $\rho$ is density at depth $z, \rho_{\mathrm{i}}$ the density of ice $\left(920 \mathrm{~kg} \mathrm{~m}^{-3}\right), \rho_{\mathrm{s}}$ the density of

276 surface snow $\left(300 \mathrm{~kg} \mathrm{~m}^{-3}\right)$, and $\mathrm{C}$ is a constant which has been set to $1.9 / z_{t}$ where $z_{t}$ is the depth of the firn-ice transition. $z_{t}$ varies with accumulation rate and surface climate, and has been put to $70 \mathrm{~m}$, a typical value for Greenland (Paterson, 1994).

Lastly, the tundra area has also been covered with the winter 1990-1991 snow pack since the start of the simulation takes place on the first of May 1991. Table 1

282 and Figure 1 summarize the details of the snow and ice initial state.

Table 1: Snow-ice model initial state characteristics.

\section{Table 1}




\section{Evaluation of the model results}

291 Model grid point results are instantaneous values averaged for the whole grid cell area. Comparing those values with local observations must be done carefully. The model grid cell closest to the observation site doesn't necessarily have the same

294 elevation as the observation site. Moreover, sub-grid topography roughness and local surface variability (surface albedo, surface emissivity and soil heat capacity) can locally influence the air motion and thermodynamic air characteristics. Higher

297 up the ice sheet, in the dry snow zone, these effects are likely less important since the surface is more homogeneous and flat. However, in the lower ablation zone and in the tundra area these effects may be very important. For example,

300 measurements at Kangerlussuaq $\left(67.01^{\circ} \mathrm{N}\right.$ and $\left.50.70^{\circ} \mathrm{W}\right)$ in the tundra area on west Greenland are influenced by the local conditions since the weather station is situated near the local airport where the surface is covered by asphalt. Table 2

303 gives an overview of the locations used in the comparison. Data from one coastal weather station operated by the Danish Meteorological Institute and from four onice sites have been used. One of the ice sheet stations is situated in the dry snow 306 area (AWS-Klinck), two others are located close to the long-term equilibrium line (ETH-Camp and GIMEX-M9), the last one (GIMEX-M6) is in the ablation zone.

\section{Table 2}

\section{3.1. Model evaluation at ETH-Camp}

ETH-Camp is located some $40 \mathrm{~km}$ far from the ice sheet margin, close to the longterm equilibrium line. In the model, it is located in a grid cell inside the ice sheet

315 ablation zone neighbouring the equilibrium line altitude (ELA). A description of the 1991 intensive measurement campaign at ETH-Camp is given in Ohmura et al. (1992). In this section we will compare in detail MAR modelled and observed

318 variables at ETH-Camp for the period between May 9 and August 30 in 1991 (see Figure 2 and Table 3). This is done in order to explain some of the strong points and deficiencies related to the coupling of the atmospheric model with the snow model. Also the ERA-15 fields interpolated on the MAR grid have been added in 
the comparison. ERA-15 fields are linearly interpolated from the 'reduced' Gaussian grid which was used to construct the ERA-15 re-analysis. At 70 deg

324 North, the ERA-15 west-east resolution is 2.8125 degrees which corresponds to a horizontal resolution of about $106 \mathrm{~km}$. This coarse resolution makes comparisons with point observations difficult. Interpolated ERA-15 values close to the ice sheet

327 margin will be influenced by the presence of the tundra area.

\section{Figure 2}

330 Figure 2: Comparison between observed (dotted), MAR (solid) and ECMWF (dashed) modelled air temperature, relative humidity, wind speed, wind direction and surface pressure (daily average values) at ETH-Camp during the whole simulation.

During the whole period, MAR simulated surface boundary layer (SBL) temperatures are in close agreement with the observations. On the contrary, the

336 ERA-15 SBL temperatures are overestimated during the month of July. Furthermore the ERA-15 humidity and wind speed in the SBL are underestimated during that period, while the same variables in MAR are in closer agreement with

339 the observations (see also Table 3 ).

These deficiencies are probably caused by a coarse representation of the ECMWF planetary boundary layer. First the larger height of the first vertical layer in the

342 ECMWF model (roughly $40 \mathrm{~m}$ ) compared to that of the MAR model (roughly $2 \mathrm{~m}$ ) induces errors in the representation of the katatabic vertical structure. In fact, the vertical profile of the persistent katabatic wind speed exhibits a low level wind

345 speed maximum that is not resolved in the ECMWF model. The katabatic winds are too weak in the ECMWF model and this is responsible for an underestimation of the downward sensible (upward latent) surface heat fluxes, leading to an

348 additional overestimation of the SBL temperature and a subsequent too weak katabatic wind forcing. Note also that the surface slope is not well represented in ERA-15 because of its coarse horizontal resolution. Besides the resolution issue,

351 simulated winds are also underestimated due to the first order turbulence closure schemes inside the ECMWF ERA-15 model (Gibson et al., 1999) that are know not to be adequate during stable conditions (Denby, 2001).

Table 3 : Statistics at ETH-Camp during the summer of 1991 based on 6-hourly values for the 


\section{Table 3}

360 In addition to Figure 2 which shows daily average values during the whole simulation period, Figure 3 demonstrates MAR ability to simulate correctly the daily cycle for the most important near-surface atmospheric parameters during a

363 short period (June). The weather encountered during this month can be divided into two distinct periods. Before the 16th of June, the weather was characterized by a high-pressure synoptic situation that led to clear skies with large daily cycles

366 in temperature, humidity and wind speed. Afterwards, the surface pressure dropped until the end of the month and clouds appeared which lead to damped daily cycles of these atmospheric variables.

\section{Figure 3}

Figure 3: Comparison between observed (dotted) and MAR modelled (solid) air temperature, air 372 specific humidity, wind speed, wind direction, surface downward solar radiation and surface downward longwave radiation at ETH-Camp from half-hourly values during June 1991.

375 The surface energy balance, which drives the surface mass balance, is largely controlled by the radiative fluxes and the surface albedo and in a lesser extent by the turbulent fluxes (van den Broeke et al., 1994). Table 4 contains the observed averages, MAR bias and root mean square error for the radiative fluxes and this for the whole duration of intensive radiative measurements at ETH-camp (June 3 until August 18), for cloudy days and for clear-sky days.

Table 4: Statistics of the radiative fluxes (in $\mathrm{W} \mathrm{m}^{-2}$ ) at ETH-Camp during the summer of 1991 (3 June - 18 August 1991) based on half hourly values.

MAR overestimates the amount of incoming solar radiation. This overestimation $387\left(+26.5 \mathrm{~W} \mathrm{~m}^{-2}\right)$ is somewhat compensated by an underestimation $\left(-14.7 \mathrm{~W} \mathrm{~m}^{-2}\right)$ of the downward longwave radiation. Nevertheless, due to the high surface albedo for snow (about $75 \%$ ), one has to conclude that the net radiation balance is still underestimated by about $8 \mathrm{~W} \mathrm{~m}^{-2}$.

Comparison between cloudy and clear sky conditions indicates that most of the 
393 errors are caused during cloudy conditions. This is also shown in Figure 3 where the largest errors in the simulated downward longwave radiation occur during cloudy days, i.e. days with reduced solar downward radiation. In MAR, longwave

396 radiation is calculated with the scheme of Morcrette (1984) that was designed for use in GCM models and that was also used during the calculation of the ERA-15 re-analysis. It was found by Morcrette (2002) that this version of the longwave 399 scheme underestimates the downward infrared radiation at the surface. In addition, errors in the simulated cloud emissivities could further contribute to that negative bias. This problem will be corrected in the future by using the new ECMWF radiative transfer scheme (Morcrette, 2002).

During the 1991 ETH-expedition, eddy-correlation measurements were made to 405 evaluate the turbulent momentum and heat fluxes (Forrer and Rotach, 1997). Data is only available during some periods of the ablation season. Therefore, we have compared the model results with observations by means of scatter plots (Figure 4). 408

\section{Figure 4}

Figure 4: Comparison between simulated and observed $2 \mathrm{~m}$ friction velocity (left) and sensible heat

411 flux (right) at ETH-Camp during the summer of 1991.

Simulated friction velocities are in agreement with the observations for values 414 lower than $0.3 \mathrm{~m} / \mathrm{s}$ but show a positive bias at higher friction velocities. The agreement is acceptable for the sensible heat flux at $2 \mathrm{~m}$ (negative values represent downward heat fluxes) although MAR sometimes generates an upward sensible

417 heat flux, contrary to the observations. It is difficult to make definite conclusions with only observations during some periods. Longer term continuous measurements are needed given the uncertainty on eddy-correlation turbulent flux measurements on sloping melting surfaces (Ohmura et al., 1992).

\section{Figure 5}

423 Figure 5: Top: Observed (dotted), MAR (solid) and ECMWF (dashed) cumulative precipitation at ETH-Camp; Middle: same as above but for the surface albedo; below: same as top graph but for the snow pack height.

The surface albedo variations, observed at ETH-Camp between the start of the 
simulation and the end of July (Figure 5), are solely caused by snow grain metamorphism processes because the surface was covered with a sufficiently thick snow pack so that the underlying ice was not interfering. During this period, it can be seen (middle graph in Figure 5) that MAR modelled snow albedo closely

432 follows the observed snow albedo variations, i.e. the lowering of the albedo due to growing snow grains when melt takes place and the abrupt increases due to snow falls simulated by the atmospheric model component. During these snow falls,

435 fresh snow crystals with a high reflectance are deposited on top of the older larger snow grains. In particular, the timing of the onset and ending of the major melting period (3-26 July) coincides with the observations.

438 The disagreement at the beginning of August (01/08/1991 - 10/08/1991) is caused by the modelled ice layers at the surface of the snow pack. These ice layers with a low albedo of 0.55 , form because of the lower air temperatures in combination

441 with the saturated snow pack. It should be noticed that at the same moment, slush was observed in the surroundings of the site. This suggests that the slush is probably not well treated by the snow model during refreezing conditions.

444 Afterwards (11/08/1991 - 16/08/1991), due to the previously overamplified melt due to the underestimated surface albedo, the snow pack has become too thin in comparison with the observations. In these conditions, the model surface albedo is

447 found to fluctuate between the high albedo coming from fresh snow and the low albedo (0.55) of the underlying ice. At the end of the simulation, simulated surface albedo values are again very close to the observations.

450 It should be stressed that a well simulated surface albedo is only possible provided all conditions are fulfilled. In particular, the surface albedo model should be sufficiently detailed but also the initial conditions should be correct. For example,

453 the simulated height of the snow pack upon the ice at ETH-Camp decreases slightly too fast (lower graph in Figure 5) which causes the ice to appear to rapidly. This error can partly be explained by the somewhat underestimated mass

456 balance of the initial snow pack caused by using a too small snow density at the beginning of the simulation $\left(300 \mathrm{~kg} \mathrm{~m}^{-3}\right)$. Indeed the initial thickness of the snow pack is comparable to the observed one. This has been verified by comparison

459 with the observed snow pack mass balance at ETH-Camp at the start of the simulation.

462 The use of a snow albedo which depends on the snow surface temperature in the ERA-15 re-analysis project clearly induces a too small albedo when melt occurs. It 
can be seen that the ECMWF simulated surface albedo decreases down to 0.4 already at the beginning of June. This oversimplified albedo scheme has been updated in the actual ECMWF forecast model as well as in the production of the new ERA-40 re-analysis dataset (personal communication A.Beljaars).

\subsection{Model evaluation at the K-transect}

During the GIMEX-91 experiment, 7 weather stations, 3 on the tundra and 4 on 471 the ice sheet, were placed along the $\mathrm{K}$ (angerlussuq)-transect at $67{ }^{\circ} \mathrm{N}$ in west Greenland by the University of Utrecht and the Free University of Amsterdam. For more information about the experiment, the reader is referred to Van den 474 Broeke et al. (1994), who give a detailed description of the measurement campaign. We will use data from only two stations (GIMEX-M6 and GIMEXM9) which are both located on the ice sheet. MAR horizontal resolution (20 km)

477 does not allow to compare model output with measurements from the other locations situated at 2.2 and $6.9 \mathrm{~km}$ from the ice sheet border. GIMEX-M6 and GIMEX-M9 are located at approximately 40 and $90 \mathrm{~km}$ from the ice sheet border

480 (Table 2).

\section{Figure 6}

483 Figure 6: MAR (solid) and observed (dotted) air temperature, wind speed, wind direction, surface downward solar radiation and surface albedo evolution at GIMEX-M6.

486 Figures 6 and 7 compare MAR results with observations at GIMEX-M6 and GIMEX-M9, respectively. For GIMEX-M6, average hourly observations are available from 10 June until 24 July. At GIMEX-M9, half hourly observations for

489 the 5-24 July period have been obtained. Unfortunately, no turbulent flux measurements by eddy-correlation were available for these GIMEX-sites.

Table 5: Statistics at GIMEX-M6 (hourly values) and GIMEX-M9 (half-hourly values) during the summer of 1991.

\section{Table 5}

Air temperature, air humidity, wind speed and wind direction are accurately simulated (Table 5). Solar downward radiation is overestimated which confirms 
498 the results at ETH-Camp although the solar radiation evolution (Figure 6) shows that the cloud cover frequency is mostly correctly simulated by the model.

501 The overestimated simulated surface albedo in MAR between 10th of June and 4th of July at GIMEX-M6 is due to the presence of an initial snow pack in the MAR model. Actually, at the beginning of the measurements, the ice sheet surface 504 at GIMEX-M6 was snow-free. After the modelled snow pack in MAR has melted away ( $\left.4^{\text {th }} \mathrm{July}\right)$, the surface albedo agrees much better with the observed values.

\section{Figure 7}

Figure 7: as in Figure 6 but at GIMEX-M9. The dashed curves are from a sensitivity experiment in which the surface albedo was held constant at 0.8 during the whole simulation and this over the 510 whole ice sheet.

At GIMEX-M9, the observed surface albedo between 5-24 July decreases from

5130.8 to 0.65 (see Figure 7). Surface melt occurred on every day only interrupted by one snowfall on July $16^{\text {th }}$. MAR modelled surface albedo also decreases due to growing snow grains. However the modelled decrease is slightly too small.

516 Ablation at GIMEX-M9 is characterized by a strong daily cycle with melt during the day and refreezing during the night (observed air temperatures fall below 0 $\left.{ }^{\circ}-\mathrm{C}\right)$. This is successfully simulated by MAR.

The importance of an accurately simulated surface albedo clearly shows up when the results of a sensitivity experiment are analyzed in which the surface albedo is

522 held constant at 0.8 over the whole sheet. This is shown for the GIMEX-M9 location (Figure 7) where the use of a constant albedo clearly leads to stronger daily cycles because less heat from meltwater refreezing is available to act against

525 the cooling during the night. Moreover, a too high surface albedo tends to increase the surface inversion, which increases the katabatic wind speed (visible between 22-27 July). But on average, the differences in the simulated atmospheric fields 528 between both experiments are rather small. This is also the case at GIMEX-M6 and ETH-Camp (not shown here).

However, there is a significant impact on the simulated mass balance (Table 6).

531 For example at GIMEX-M9 in the percolation zone, the initial snow height equals $141 \mathrm{~cm}$ above the ice. At the end of the simulation, this height is reduced to $61 \mathrm{~cm}$ in the reference experiment while it is $50 \%$ higher $(91 \mathrm{~cm})$ in the albedo 
534 sensitivity experiment. The impact is even larger at GIMEX-M6 situated in the ablation zone characterized by low albedo values. At GIMEX-M6, the appearance of ice at the surface is simulated on July $8^{\text {th }}$ in the reference experiment with the 537 melt of an additional $130 \mathrm{~cm}$ of ice afterwards. At the end of the constant 0.8 albedo experiment, the winter snow pack at GIMEX-M6 is not even completely melted away and $17 \mathrm{~cm}$ of snow remains above the ice at the end of August.

Table 6: Simulated surface mass balance components in the different model mass balance zones for the reference experiment and the constant 0.8 albedo sensitivity experiment. The absolute mass

543 balance terms are expressed in mmWE. Negative numbers indiquate mass losses. Net melt is the amount of melt adjusted for retention of meltwater inside the snow pack and eventually refreezing. The relative changes are calculated as [(2) - (1)] / (1) with (1) the reference figures and (2) the 546 constant 0.8 albedo results.

\section{Table 6}

549 On average over the ice sheet (Table 6), melt decreases by more than $60 \%$ in the constant albedo simulation compared to the reference experiment. The other mass balance components only change in a minor wayexcept the evaporative mass loss

552 which decreases by $10-15 \%$ in the model ablation and percolation zone. Therefore, the use of a constant 0.8 albedo has little impact on the simulation of the atmospheric variables but will lead to a significant underestimation of the

555 modelled melt. In the perspective of mass balance calculations, this is of capital importance.

\section{3.3. Model evaluation in the high dry snow zone (Summit)}

AWS-Klinck is situated in the neighbourhood of the Greenland ice sheet summit.

561 The simulated temperature is in agreement with observations during the day but is underestimated during the night when the temperature is below $-25^{\circ} \mathrm{C}$ (Figure 8). This leads to a negative temperature bias of about $3^{\circ} \mathrm{C}$ (Table 7). Part of the

564 negative bias can be explained by the katabatic temperature inversion and the difference in height between the model's first level and the height of the measurements. Indeed, the measurements were taken at a height of $3 \mathrm{~m}$ above the

567 surface while the model lowest level is situated at less than $1.5 \mathrm{~m}$ above the surface. In fact, due to the elevated surface height of AWS-Klinck, the lowest 
model level (pressure levels), which at mean sea level is normally situated at $2 \mathrm{~m}$

570 above the surface is situated at $1.5 \mathrm{~m}$ above the surface near the summit of the Greenland ice sheet. Secondly, as already explained during the discussion of the results at ETH-Camp, Morcrette (2002) has shown that the radiative model used

573 in MAR (as well as in the ERA-15 re-analysis) underestimates the downward infrared radiation for cold clear sky situations. This is responsible for an underestimation of the air temperature, especially at the top of the ice sheet where

576 cold clear sky situations dominate. Again, the accuracy of the radiation physics in polar conditions needs further improvement.

\section{Figure 8}

Figure 8: MAR (solid) and observed (dashed) air temperature, wind speed and surface pressure at AWS-Klinck which is located close to the ice sheet summit.

Table 7: Statistics at AWS-Klinck and Kangerlussauq during the summer of 1991 based on 6hourly values.

\subsection{Model evaluation at Kangerlussuaq}

588 At the start of the simulation, the tundra area near Kangerlussuaq is covered with snow which explains why simulated air temperatures do not raise above $0{ }^{\circ} \mathrm{C}$. However, when all snow has melted away in the model, simulated temperatures

591 agree very well with the observed ones (Figure 9 and Table 7) stressing the need for correct initial conditions for the simulation of the summer climate.

In this context, it also worth mentioning the results of Denby (2001) who found an

594 important sensitivity of the simulated turbulent and longwave heat fluxes in the ice sheet ablation zone depending on the state of the tundra (snow covered or not).

\section{$597 \quad$ Figure 9}

Figure 9: MAR (solid) and observed (dotted) air temperature, relative humidity, wind speed, surface pressure and cumulative precipitation at Kangerlussuaq.

The large surface pressure bias is caused by the difference in surface height (see 
Table 2). The resolution used is clearly not yet sufficient to take explicitly into

603 account the narrow fjords which runs from the sea towards the ice sheet margins through the tundra area.

606 Finally, MAR modelled precipitation corresponds closely with the observations until half August (lower graph in Figure 9). Thereafter, about 4 precipitation events are simulated by MAR at the right moment but with a too low intensity.

609 The precipitation bias can be due to very localised orographic effects in the Kangerlussuaq fjord. 


\section{Conclusions and perspectives}

615 A coupled atmosphere-snow regional climate model (MAR) applied over south Greenland with a high horizontal resolution of $20 \mathrm{~km}$ has been nested into ECMWF ERA-15 re-analysis. Lateral boundary conditions are updated every 6

618 hours. Due to the coupling of the regional climate atmospheric model with the snow model, the snow albedo over the ice sheet is calculated by the snow model from the precipitated fresh snow. Inside the snow model, the history of the

621 evolution of the snow grain characteristics (sphericity, dendricity and grain size) is used to calculate the surface albedo.

The evaluation of the surface albedo simulation at ETH-Camp, GIMEX-M6 and

618 GIMEX-M9 showed that an accurate surface albedo simulation, which is a requisite for a good surface mass balance simulation, strongly depends on the state of the snow pack at the start of the ablation season. Therefore, future high-

621 resolution simulations of the Greenland surface mass balance by means of coupled atmospheric-snow models should not only focus on the summer season but also on the winter season. In that way, the initial conditions can be obtained more

624 accurately. Moreover close to the ice sheet margin around the K-transect, the ice sheet surface is found to be snow-free at the start of the simulation. Winter precipitation is not so important in this region (Bromwich et al., 2001a) but

627 certainly not equal to zero. On the other hand, the katabatic winds are very persistent and strong in this region which suggests snow drift to take place. This, as well as the role of evaporation and sublimation, should be further investigated 630 in the future.

618

Evaluation of the model surface radiative fluxes points to an overestimation of the solar downward radiative flux and an underestimation of the longwave radiative

621 flux although the simulated inter-daily variability due to cloud cover was mostly in agreement with the observations. The underestimation of the downward longwave radiative flux with the present version of the longwave scheme has been

624 pointed out by Morcrette (2002) and will be corrected in the future by using an updated version of the radiative scheme. Also the role of the microphysical parameterizations should be further investigated. 
621 A sensitivity experiment in which the surface albedo was held constant at 0.80 over the whole ice sheet underlined the strong influence of this parameter on the simulation of the surface mass balance. This is particularly relevant in the model

624 ablation zone where ice appears at the surface during the summer melting season. A constant 0.8 albedo influences weakly the atmospheric variables as in Cassano et al. (2001). However on average over the ice sheet, there is $60 \%$ less melt. In the 627 perspective of mass balance calculations, it is therefore of capital importance to use a variable albedo which evolves according to the state of the snow-ice surface.

The presented evaluation of the coupled atmosphere-snow Greenland climate

624 model opens new perspectives in the study of the Greenland surface mass balance because of the coupling between the atmosphere and the snow model. In a next step, the model should be applied over the whole Greenland ice sheet and

627 simulations covering longer time periods should be foreseen in order to study for example, the origins and mechanisms behind the inter-annual variability of the Greenland surface mass balance. Also sublimation and the contribution of

630 refreezing to the surface mass balance are topics that should be addressed with the present model.

624

\section{Acknowledgments}

Filip Lefebre was financed by the Belgian Scientific Research Program "Global

627 Change and Sustainable Development (contract CG/10/09B)" of the Prime Minister's Science Policy Office when writing this paper. We are very grateful to the Belgian Royal Meteorological Institute (KMI-IRM) for opening the access to

630 the European Centre for Medium-Range Weather Forecasts (ECMWF) data services. Dominique Lucas (ECMWF, Reading) is thanked for help with the ERA data. The authors would like to thank The Antarctic Meteorological Research

633 Center, Space Science and Engineering Center, University of Wisconsin-Madison a well as the National Science Foundation for the AWS-Klinck data. Philippe Huybrechts (Vrije Universiteit Brussel, Brussels, Belgium) is kindly thanked for 636 providing the Greenland topography and land mask data. We gratefully acknowledge the Belgian Fonds de la Recherche Fondamentale Collective, for providing computer facilities under project 2.4556.99 "Simulation numérique et 
LEFEBRE ET AL.: EVALUATION REGIONAL CLIMATE SIMULATION OVER GREENLAND 05.04.07 11:14:41

627 traitement de données". 


\section{References}

Ambach W (1988) Heat balance characteristics and ice ablation. western EGIG-profile, Greenland. In: Thomsen T, Sögaard H, Braithwaite R (eds) Applied hydrology in the development of northern basins, Danish Society for Arctic Technology, Copenhagen, pp 59-70

Benson CS (1962) Stratigraphic studies in the snow and firn of the Greenland ice sheet. SIPRE(CRREL) Res Rep 70, CRREL, Hannover NH, 93 pp

Brasseur O, Gallée H, Creutin J-D, Lebel T, Marbaix P (2002) High resolution simulations of precipitations over the Alps with the perspective of coupling with a hydrological model. In: Beniston M (eds) Climate Change: Implications for the hydrological cycle and for water management. Advances in Global Change

639 Research, vol. 10, Kluwer Acadamic Publishers, Dordrecht (The Netherlands) and Boston (USA), pp 75100

Box J, Steffen K (2001) Sublimation on the Greenland ice sheet from automated weather station observations, J Geophys Res 106: 33,965-33982

Bromwich D, Chen Q-S, Bai L, Cassano E, Li Y (2001a) Modeled precipitation variability over the Greenland ice sheet. J Geophys Res 106:33,891-33,908

Bromwich DH, Cassano JJ, Klein T, Heinemann G, Hines KM, Steffen K, Box JE (2001b) Mesoscale modeling of katabatic winds over Greenland with the Polar MM5. Monthly Weather Review 129(9): 2290-2309

Davies H (1983) Limitations of some common lateral boundary schemes used in regional NWP models. Mon Wea Rev 111:1002-1012

660

Deardorff J (1978) Efficient prediction of ground surface temperature and moisture with inclusion of a layer of vegetation. J Geophys Res 83:1889-1903

663

Denby B (2001) Modelling and interpretation of turbulent fluxes in katabatic flows: applications to glaciers and the Greenland ice sheet. $\mathrm{PhD}$ thesis, Universiteit Utrecht

Ekholm S (1996) A full coverage, high-resolution, topographic model of Greenland computed from a variety of digital elevation data. J Geophys Res 101(B10):21,961-21,972

669

Forrer J and Rotach W (1997) On the turbulence structure in the stable boundary layer over the Greenland ice sheet. Bound-Layer Meteor 85:111-136

Gallée H (1995) Simulation of the mesocyclonic activity in the Ross Sea, Antarctica. Mon Wea Rev 
Gallée H and Duynkerke P (1997) Air-snow interactions and the surface energy and mass balance over the melting zone of West Greenland during GIMEX. J Geophys Res 102:13,813-13,824

Gallée H, Guyomarc'h G, Brun E (2001) Impact of snow drift on the Antarctic ice sheet surface mass balance: Possible sensitivity to snow-surface properties. Bound-Layer Meteorology 99 (1): 1-19

Gallée H and Schayes G (1994) Development of a three-dimensional meso- $\gamma$ primitive equations model. Mon Wea Rev 122:671-685

Gallée H, Fontaine de Ghélin O, van den Broeke MR (1995) Simulation of atmospheric circulation during the GIMEX-91 experiment using a meso- $\gamma$ primitive equations model. J Climate 8:2843-2859

Gibson JK, Kållberg P, Uppala S, Hernandez A, Nomura A, Serrano E (1999) ERA-15 Description (Version 2 - January 1999), ECMWF Re-analysis Project Report Series, European Centre for Medium-Range Weather Forecasts, Reading, UK

Georgi F, Mearns L (1999) Regional climate modeling revisited, J Geophys Res 104:6335-6352

Greuell W, Konzelmann T (1994) Numerical modelling of the energy balance and the englacial temperature of the Greenland ice sheet. Calculations for the ETH-Camp location (West Greenland, $1155 \mathrm{~m}$ a.s.1.). Global Planet Change 9:91-114

Hanna E, Valdes P (2001) Validation of ECMWF (re)analysis surface climate data, 1979-1998, for Greenland and implications for mass balance modelling of the ice sheet. Int J Climatol 21:171-195

Heinemann G (1999) The KABEG '97 field experiment: An aircraft-based study of katabatic wind dynamics over the Greenland ice sheet. Bound-Layer Meteor 93:75-116

Houghton J, Ding Y, Griggs D, Noguer M, van der Linden P, Dai X, Maskell K, Johnson C (eds) (2001)

Huybrechts P, Letréguilly A, Reeh N (1991) The Greenland ice sheet and greenhouse warming. Palaeogeogr Palaeoclim Palaeoecol 89:399-412

Key J, Wang X, Stroeve J, Fowler C (2001) Estimating the cloudy sky albedo of sea ice and snow from space. J Geophys Res 106:12,489-12,497

Lefebre F, Gallée H, van Ypersele JP, Greuell W (2003) Modelling of snow and ice melt at ETH-Camp (west Greenland): a study of surface albedo. J Geophys Res 108(D8):4231 DOI:10.1029/2001JD001160

Marbaix P (2000) A regional atmospheric model over Europe: Adaptation for climate studies and validation. $\mathrm{PhD}$ thesis Université catholique de Louvain, Louvain-la-Neuve, Belgium

Marbaix P, Gallée H, Brasseur O, van Ypersele JP (2003) Lateral boundary conditions in regional climate 
Morcrette, J.-J. (2002) The surface downward longwave radiation in the ECMWF forecast system. J. Climate 15: 1875-1892.

Morris E, Bader H-P, Weilenmann P (1997) Modelling temperature variations in polar snow using DAISY. J Glaciology 43(143): 180-191

Naithani J, Gallée H, Schayes G (2002) Marine air intrusion into the Adelie land sector of East Antarctica A study using Regional Climate Model (MAR). J Geophys Res 107(D11) DOI:10.1029/2000JD000274

Nolin A, Stroeve J (1997) The changing albedo of the Greenland ice sheet: implications for climate modelling. Ann Glaciol 25: 51-57

Nomura A (1995) Global sea-ice concentration data set for use in the ECMWF re-analysis system. Technical Report 76, ECMWF, Shinfield Park, Reading

Oerlemans J, Vugts H (1993) A meteorological experiment in the melting zone of the Greenland Ice Sheet. Bull Amer Meteor Soc 74: 355-365

Ohmura A, Steffen K, Blatter H, Greuell W, Rotach M, Stober M, Konzelmann T, Forrer J, Abe-Ouchi A, Steiger D, Niederbäumer G (1992) Energy and mass balance during the melt season at the equilibrium line altitude, Paakitsoq, Greenland ice sheet: Progress report 2. Dep. of Geography, Swiss Federal Institute of Technology, Zürich

Ohmura A, Wild M, Bengtsson L (1996) A possible change in mass balance of Greenland and Antarctic ice sheets in the coming century. J Climate 9:2124-2135

Paterson W (1994) The physics of glaciers. Pergamon/Elsevier Science Ltd, $3^{\text {rd }}$ ed

Pfeffer W, Meier M, Illangasekare T (1991) Retention of Greenland runoff by refreezing: implications for projected future sea level change. J Geophys Res 96:22,117-22,124

Reeh N (1991) Parameterization of melt rate and surface temperature on the Greenland ice sheet. Polarforschung, pp 113-128

Ritz C, Fabre A, Letréguilly A (1997) Sensitivity of a Greenland ice sheet model to ice flow and ablation parameters: consequences for the evolution through the last climatic cycle. Climate Dyn 13:11-24

Schytt V (1958) The inner structure of the ice shelf at Maudheim as shown by core drilling. Norwegian765 British-Swedish Antarctic Expedition, 1949-52, Scientific Results 4, Glaciology 2, Norsk Polarinstitutt, Oslo, pp 115-151 key findings, and future directions. J Geophys Res 106(D24): 33691-33705 
LEFEBRE ET AL.: EVALUATION REGIONAL CLIMATE SIMULATION OVER GREENLAND

05.04.07 11:14:41

771 van de Wal R, Oerlemans J (1994) An energy balance model for the Greenland ice sheet. Global Planet Change 9:115-131

774 van den Broeke MR, Duynkerke P, Oerlemans J (1994) The observed katabatic flow at the edge of the Greenland ice sheet during GIMEX-91. Global Planet Change 9:3-15 


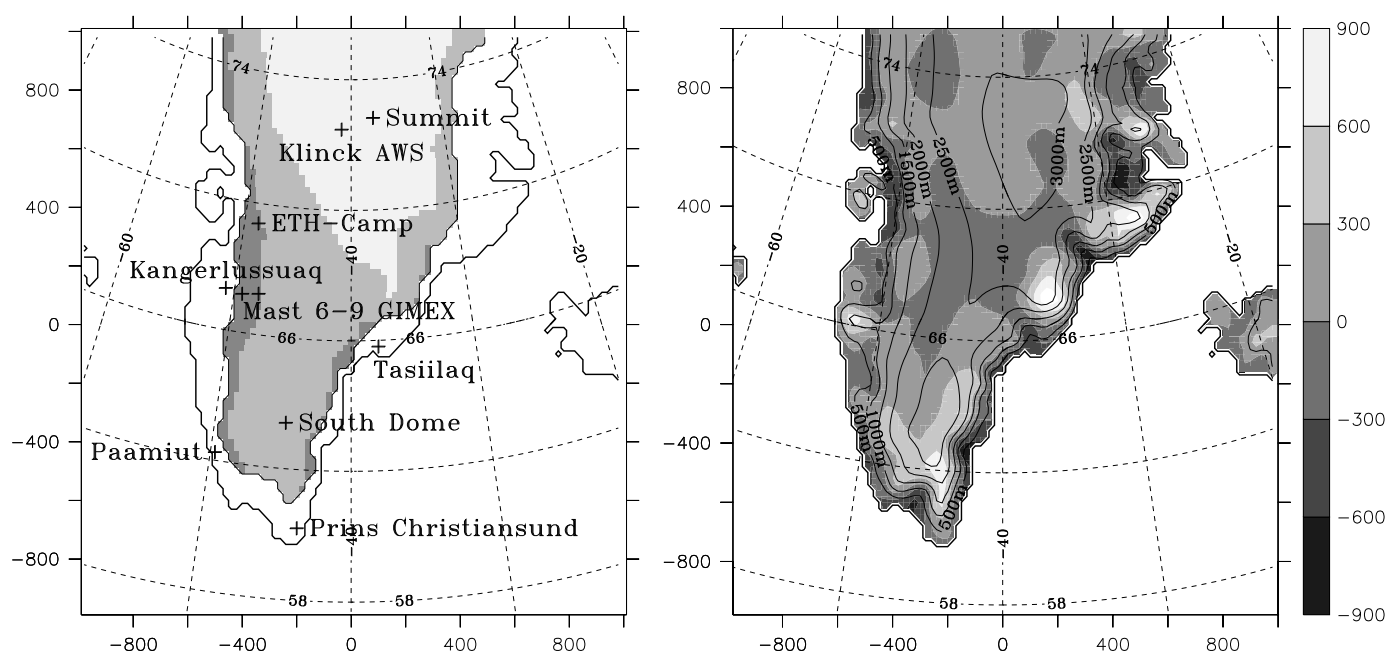

Figure 1: The prescribed distribution of MAR mass balance zones on the Greenland ice sheet and the major locations referred to in the text. From black to light grey over the ice sheet: ice sheet ablation zone, percolation zone and dry snow zone. The model ablation zone delineation is specified and taken from Reeh (1991). (Right) MAR surface height (isolines) and the difference (shades of grey) between MAR and ECMWF model surface height. 
LEFEBRE ET AL.: EVALUATION REGIONAL CLIMATE SIMULATION OVER GREENLAND

05.04.07 11:14:41
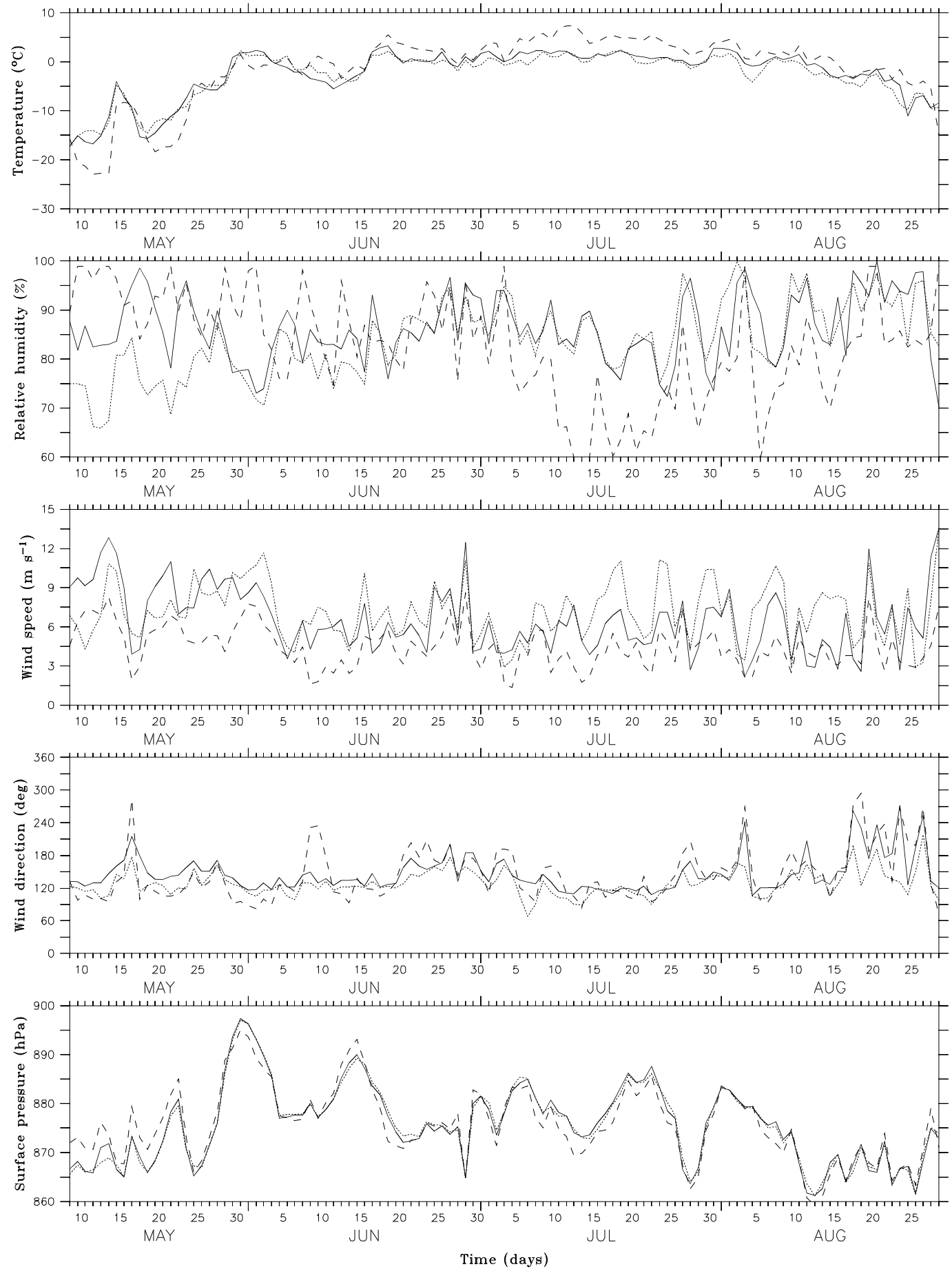

783 Figure 2: Comparison between observed (dotted), MAR (solid) and ECMWF (dashed) modelled air temperature, relative humidity, wind speed, wind direction and surface pressure (daily average values) at ETH-Camp during the whole simulation. 
LEFEBRE ET AL.: EVALUATION REGIONAL CLIMATE SIMULATION OVER GREENLAND

05.04.07 11:14:41
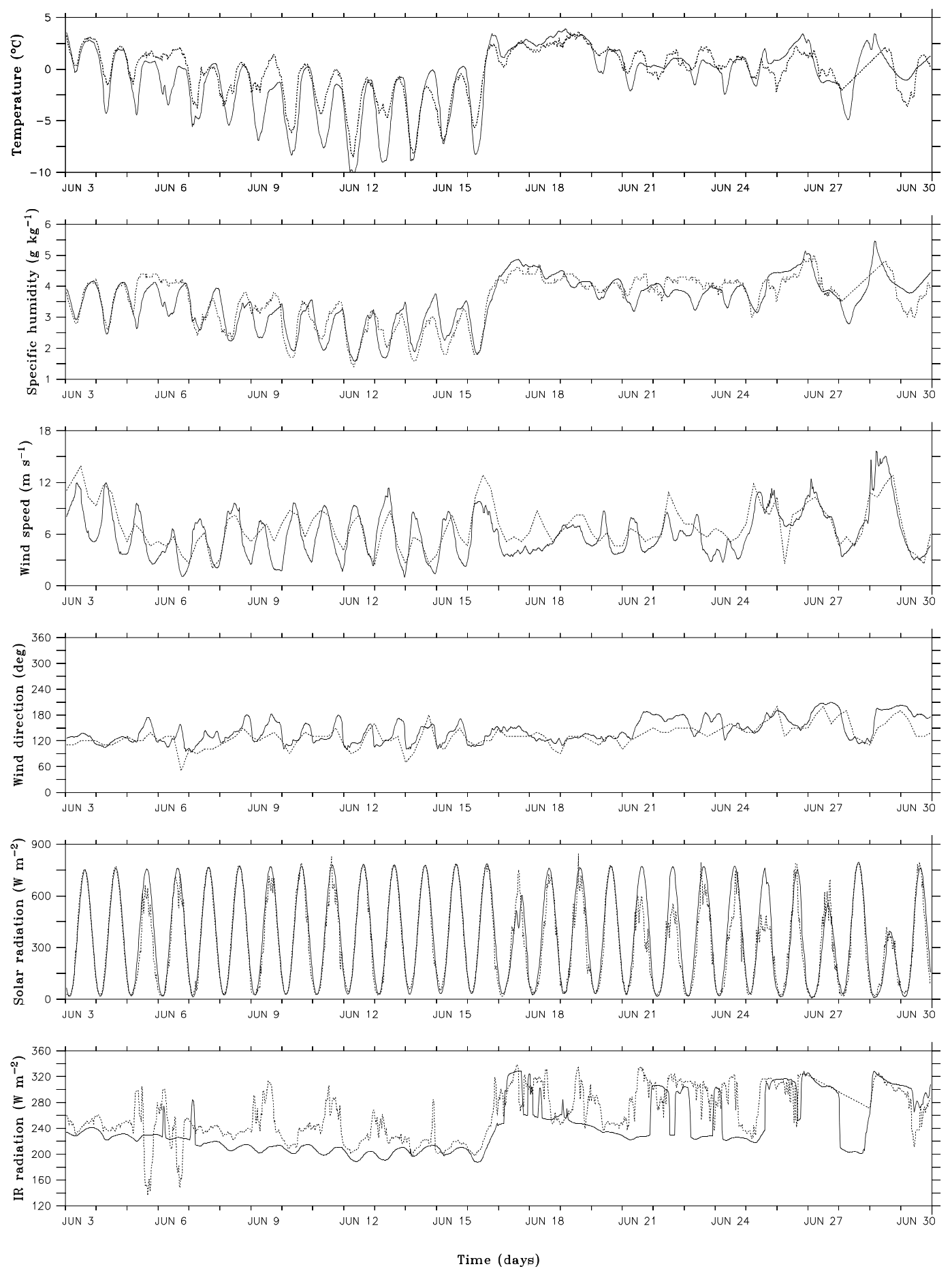

Figure 3: Comparison between observed (dotted) and MAR modelled (solid) air temperature, air specific humidity, wind speed, wind direction, surface downward solar radiation and surface downward longwave radiation at ETH-Camp from half-hourly values during June 1991. 
LEFEBRE ET AL.: EVALUATION REGIONAL CLIMATE SIMULATION OVER GREENLAND

05.04.07 11:14:41
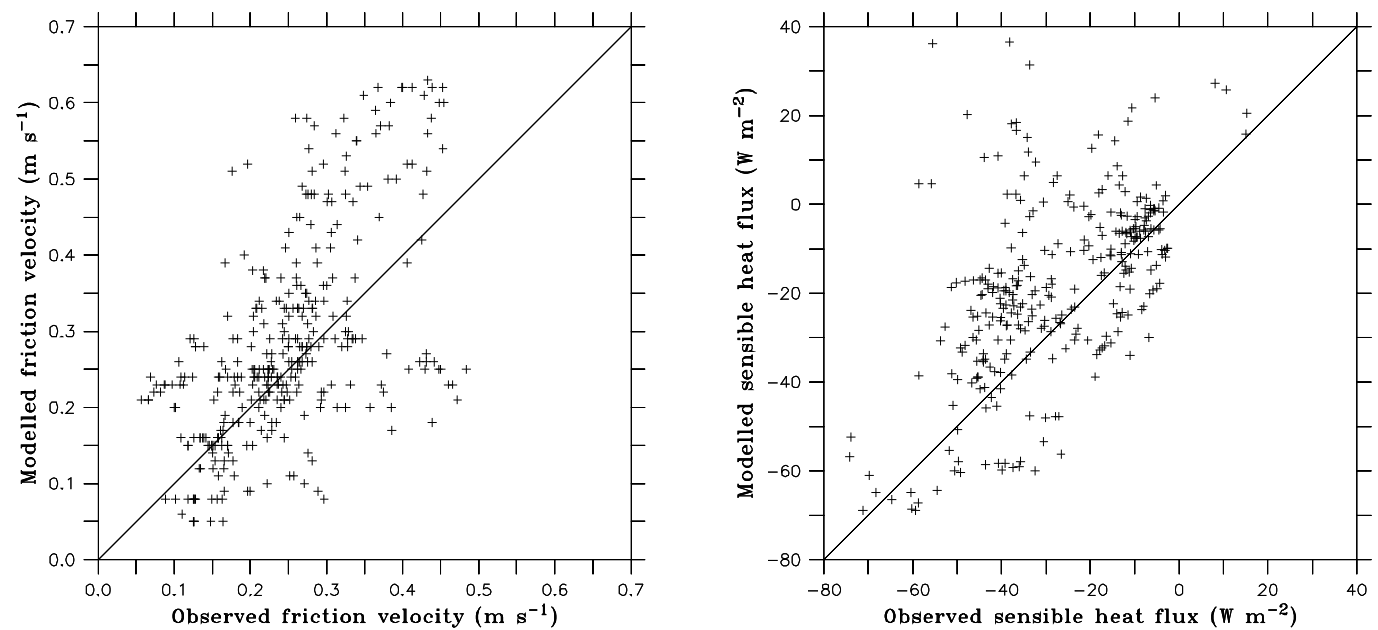

798

Figure 4: Comparison between simulated and observed $2 \mathrm{~m}$ friction velocity (left) and sensible heat flux (right) at ETH-Camp during the summer of 1991.

801 
LEFEBRE ET AL.: EVALUATION REGIONAL CLIMATE SIMULATION OVER GREENLAND

05.04.07 11:14:41
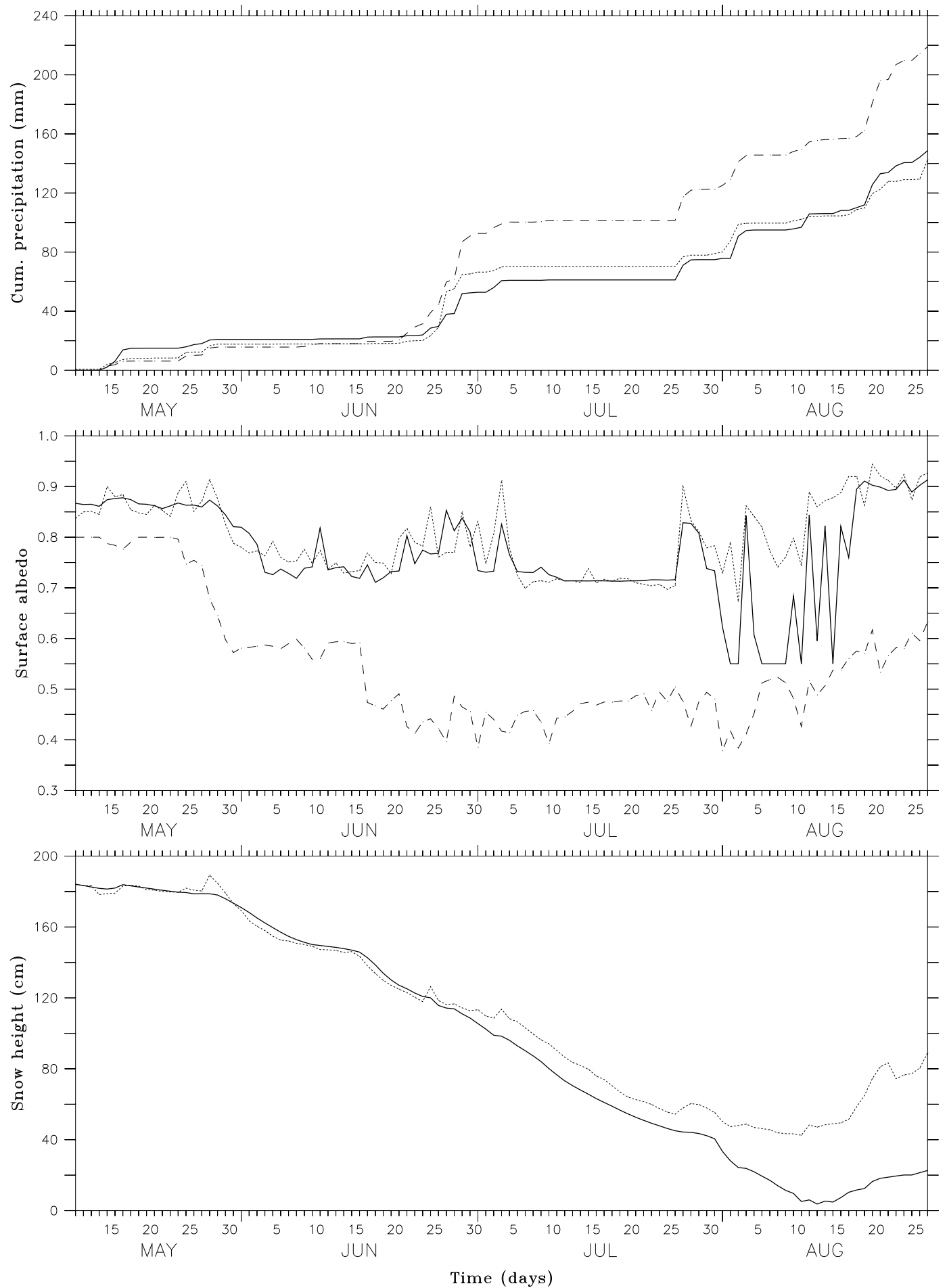

Figure 5: Top: Observed (dotted), MAR (solid) and ECMWF (dashed) cumulative precipitation at

804 ETH-Camp; Middle: same as above but for the surface albedo; below: same as top graph but for the snow pack height. 
LEFEBRE ET AL.: EVALUATION REGIONAL CLIMATE SIMULATION OVER GREENLAND

05.04.07 11:14:41
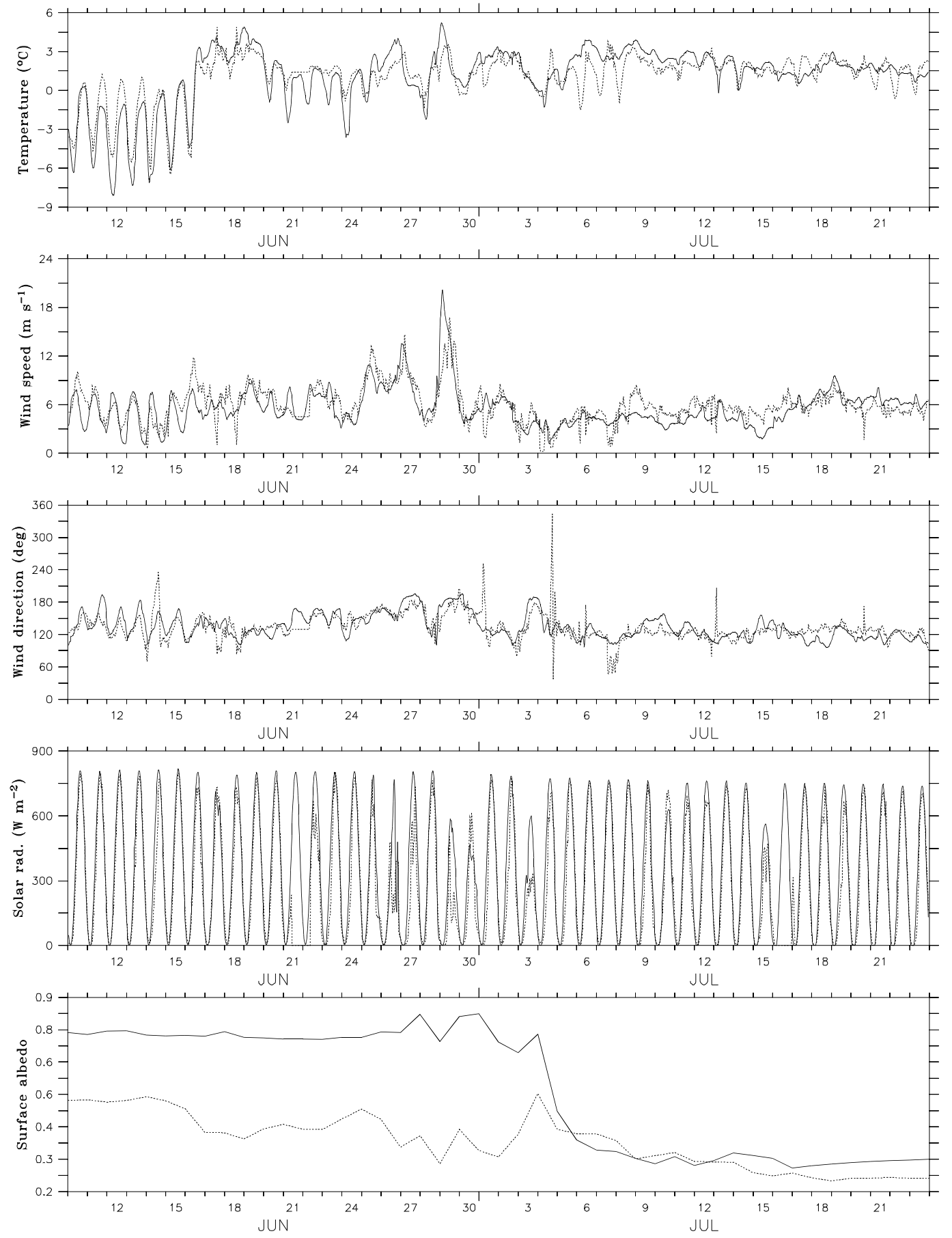

Time (days)

Figure 6: MAR (solid) and observed (dotted) air temperature, wind speed, wind direction, surface 810 downward solar radiation and surface albedo evolution at GIMEX-M6. 
LEFEBRE ET AL.: EVALUATION REGIONAL CLIMATE SIMULATION OVER GREENLAND

05.04.07 11:14:41
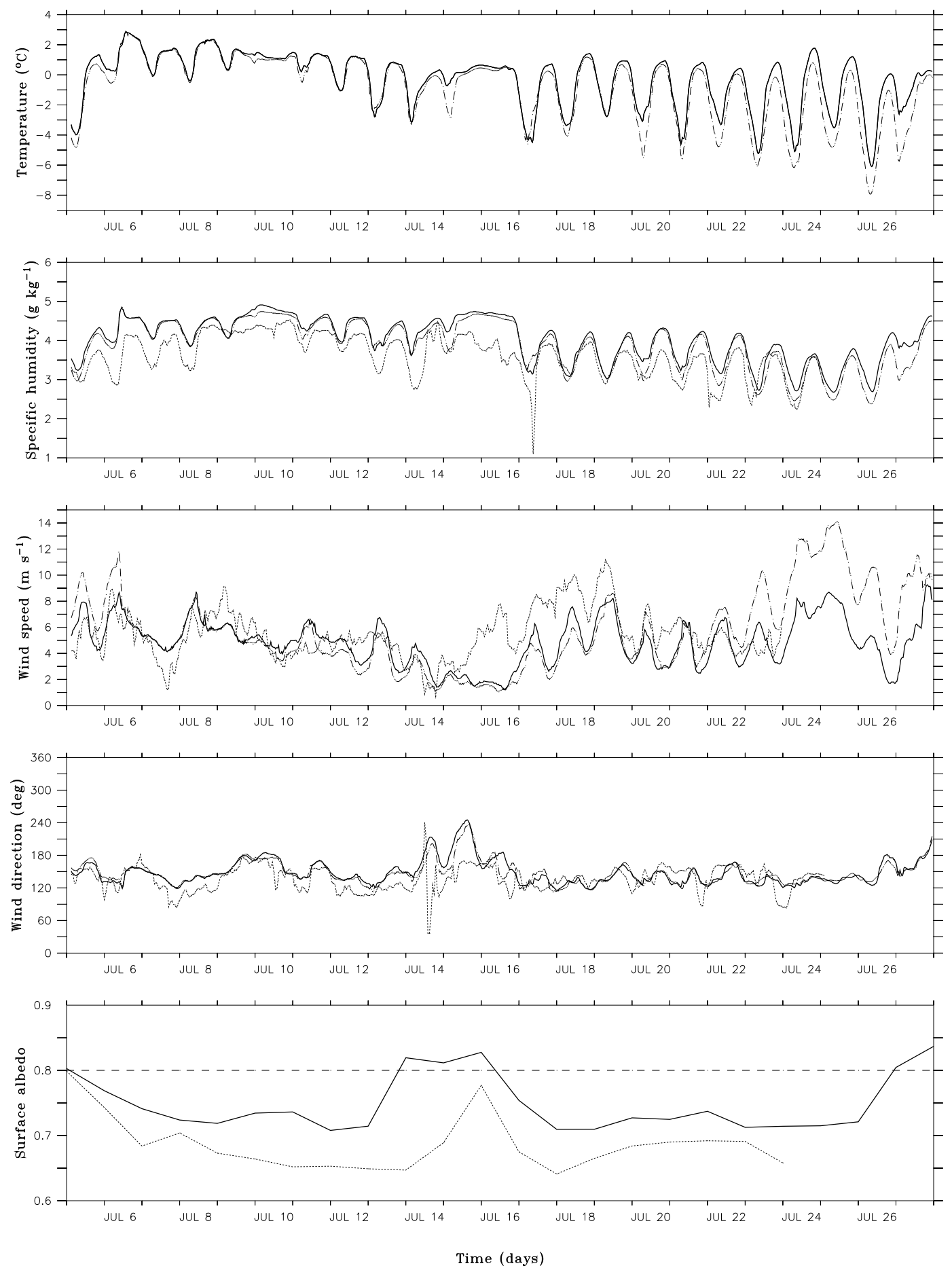

Figure 7: as in Figure 6 but at GIMEX-M9. The dashed curves are from a sensitivity experiment in

813 which the surface albedo was held constant at 0.8 during the whole simulation and this over the whole ice sheet. 
LEFEBRE ET AL.: EVALUATION REGIONAL CLIMATE SIMULATION OVER GREENLAND

05.04.07 11:14:41
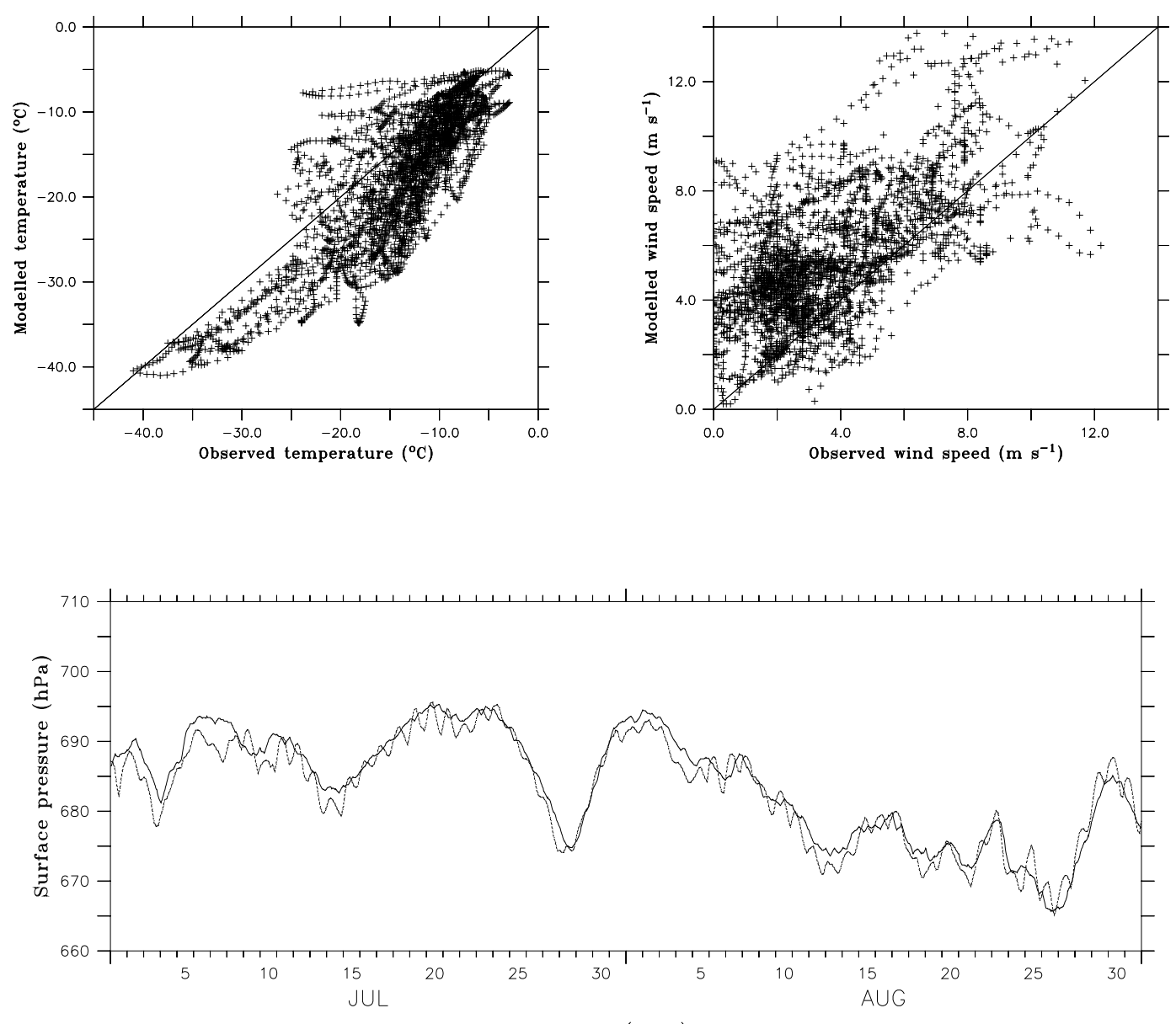

Time (days)

816 Figure 8: MAR (solid) and observed (dashed) air temperature, wind speed and surface pressure at AWS-Klinck which is located close to the ice sheet summit. 
LEFEBRE ET AL.: EVALUATION REGIONAL CLIMATE SIMULATION OVER GREENLAND

05.04.07 11:14:41
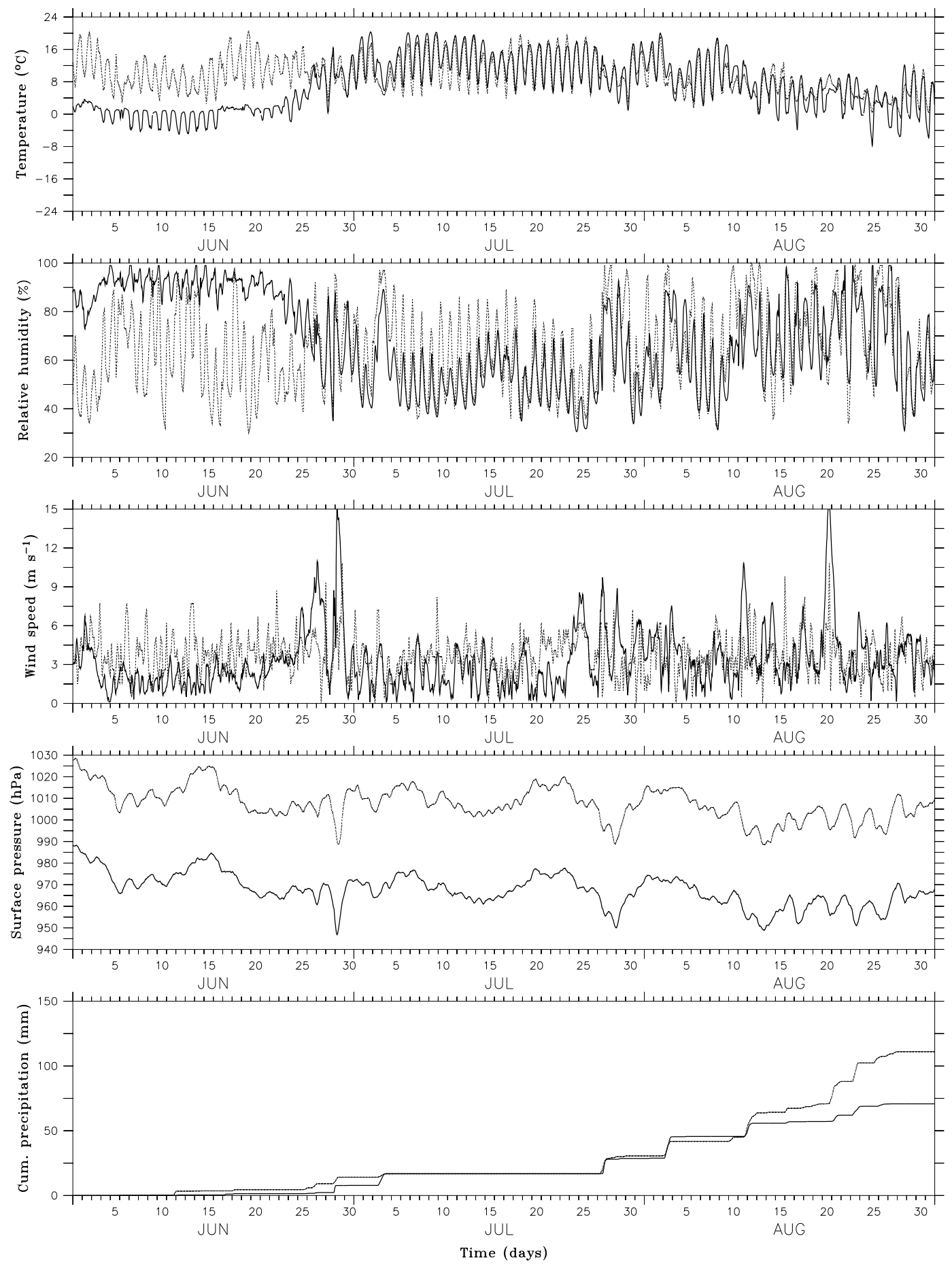

Figure 9: MAR (solid) and observed (dotted) air temperature, relative humidity, wind speed, surface pressure and cumulative precipitation at Kangerlussuaq. 
LEFEBRE ET AL.: EVALUATION REGIONAL CLIMATE SIMULATION OVER GREENLAND

05.04.07 11:14:41

Table 1: Snow-ice model initial state characteristics.

\begin{tabular}{|l|l|l|l|}
\hline $\begin{array}{l}\text { Model mass } \\
\text { balance zone }\end{array}$ & Vertical structure & $\begin{array}{l}\text { Snow-ice model } \\
\text { density }\left(\mathrm{kg} \mathrm{m}^{-3}\right)\end{array}$ & $\begin{array}{l}\text { Snow grain } \\
\text { size (mm) }\end{array}$ \\
\hline Dry snow zone & 20 m of snow & eq. 2 & 0.3 \\
\hline Percolation zone & $\begin{array}{l}\text { 20 m of snow } \\
+ \\
\text { Bromwich (2001a) 1990- } \\
\text { 1991 winter snow }\end{array}$ & 300 & 0.3 \\
\hline Ablation zone & $\begin{array}{l}\text { 20 m ice } \\
+\end{array}$ & $\begin{array}{l}\text { Bromwich (2001a) 1990- } \\
1991 \text { winter snow }\end{array}$ & $\begin{array}{l}300 \\
+\end{array}$ \\
\hline Tundra area & $\begin{array}{l}\text { Bromwich (2001a) 1990- } \\
1991 \text { winter snow }\end{array}$ & 0.3 \\
\hline
\end{tabular}


LEFEBRE ET AL.: EVALUATION REGIONAL CLIMATE SIMULATION OVER GREENLAND 05.04.07 11:14:48

825 Table 2: Geographical positions and elevations of the locations used in the comparison.

\begin{tabular}{|l|l|l|l|l|l|}
\hline Site & $\begin{array}{l}\text { Latitude } \\
\left({ }^{\circ} \mathrm{N}\right)\end{array}$ & $\begin{array}{l}\text { Longitude } \\
\left({ }^{\circ} \mathrm{W}\right)\end{array}$ & $\begin{array}{l}\text { Observed } \\
\text { Elevation }\end{array}$ & $\begin{array}{l}\text { MAR } \\
\text { elevation }\end{array}$ & $\begin{array}{l}\text { ERA } \\
\text { elevation }\end{array}$ \\
\hline ETH-Camp & 69.57 & 49.29 & 1155 & 1153 & 1266 \\
GIMEX-M6 & 67.06 & 49.35 & 1028 & 1027 & 1143 \\
GIMEX-M9 & 67.03 & 48.28 & 1520 & 1597 & 1607 \\
AWS-Klinck & 72.31 & 40.48 & 3105 & 3080 & 3019 \\
Kangerlussuaq & 67.01 & 50.70 & 50 & 340 & 692 \\
\hline
\end{tabular}


LEFEBRE ET AL.: EVALUATION REGIONAL CLIMATE SIMULATION OVER GREENLAND

05.04.07 11:14:48

Table 3 : Statistics at ETH-Camp during the summer of 1991 based on 6-hourly values for the 828 period from the $9^{\text {th }}$ of May until the $30^{\text {th }}$ of August.

\begin{tabular}{|l|r|l|l|l|l|l|l|}
\hline Variable & $\begin{array}{l}\text { Obs. } \\
\text { mean }\end{array}$ & $\begin{array}{l}\text { MAR } \\
\text { bias }\end{array}$ & $\begin{array}{l}\text { ERA } \\
\text { bias }\end{array}$ & $\begin{array}{l}\text { MAR } \\
\text { rmse }\end{array}$ & $\begin{array}{l}\text { ERA } \\
\text { rmse }\end{array}$ & $\begin{array}{l}\text { MAR } \\
\text { corr }\end{array}$ & $\begin{array}{l}\text { ERA } \\
\text { corr }\end{array}$ \\
\hline Air temperature $\left({ }^{\circ} \mathrm{C}\right)$ & -2.77 & +0.39 & +1.42 & 1.99 & 4.16 & 0.94 & 0.86 \\
Relative humidity $(\%)$ & 83.86 & +1.58 & -2.12 & 7.43 & 14.98 & 0.63 & 0.01 \\
Wind speed $\left(\mathrm{m} \mathrm{s}^{-1}\right)$ & 7.17 & -0.60 & -2.70 & 2.70 & 3.56 & 0.60 & 0.54 \\
Wind direction $\left({ }^{\circ}\right)$ & 128.6 & +18.0 & +16.5 & 35.4 & 50.0 & 0.66 & 0.59 \\
Surface pressure (hPa) & 875.8 & -0.04 & +0.00 & 1.21 & 2.69 & 0.99 & 0.94 \\
Surface albedo (-) & 0.75 & -0.05 & -0.25 & 0.11 & 0.26 & 0.53 & 0.49 \\
\hline
\end{tabular}


LEFEBRE ET AL.: EVALUATION REGIONAL CLIMATE SIMULATION OVER GREENLAND

05.04.07 11:14:48

831 Table 4: Statistics of the radiative fluxes (in $\mathrm{W} \mathrm{m}^{-2}$ ) at ETH-Camp during the summer of 1991 (3 June - 18 August 1991) based on half hourly values.

\begin{tabular}{|c|c|c|c|c|c|}
\hline Period & Variable & $\begin{array}{l}\text { Observed } \\
\text { mean }\end{array}$ & MAR bias & MAR rmse & MAR corr \\
\hline $3^{\text {rd }}$ June $\leftrightarrow$ & Solar $\downarrow$ & 301.11 & +26.46 & 78.11 & 0.96 \\
\hline $18^{\text {th }}$ August & $\mathrm{IR} \downarrow$ & 261.51 & -14.68 & 34.51 & 0.62 \\
\hline \multirow[t]{2}{*}{ Cloudy } & Solar $\downarrow$ & 222.79 & +53.83 & 117.35 & 0.92 \\
\hline & $\mathrm{IR} \downarrow$ & 302.81 & -22.68 & 47.56 & 0.27 \\
\hline \multirow[t]{2}{*}{ Clear Sky } & Solar $\downarrow$ & 340.11 & +9.60 & 47.76 & 0.98 \\
\hline & $\mathrm{IR} \downarrow$ & 240.95 & -10.95 & 25.63 & 0.42 \\
\hline
\end{tabular}


LEFEBRE ET AL.: EVALUATION REGIONAL CLIMATE SIMULATION OVER GREENLAND

05.04.07 11:14:48

834 Table 5: Statistics at GIMEX-M6 (hourly values) and GIMEX-M9 (half-hourly values) during the summer of 1991.

\begin{tabular}{|c|c|c|c|c|c|}
\hline Station & Variable & $\begin{array}{l}\text { Obs } \\
\text { mean }\end{array}$ & $\begin{array}{l}\text { MAR } \\
\text { bias }\end{array}$ & $\begin{array}{l}\text { MAR } \\
\text { rmse }\end{array}$ & $\begin{array}{l}\text { MAR } \\
\text { corr }\end{array}$ \\
\hline GIMEX-M6 & Air temperature $\left({ }^{\circ} \mathrm{C}\right)$ & 1.08 & +0.07 & 1.18 & 0.86 \\
\hline (10-24 July) & Wind speed $\left(\mathrm{m} \mathrm{s}^{-1}\right)$ & 6.00 & -0.37 & 1.76 & 0.72 \\
\hline & Wind direction $\left(^{\circ}\right)$ & 133.40 & -1.18 & 20.75 & 0.61 \\
\hline & Solar $\downarrow$ rad. $\left(\mathrm{W} \mathrm{m}^{-2}\right)$ & 304.30 & +44.37 & 99.50 & 0.95 \\
\hline & Surface albedo (-) & 0.40 & +0.16 & 0.21 & 0.76 \\
\hline GIMEX-M9 & Air temperature $\left({ }^{\circ} \mathrm{C}\right)$ & -0.34 & +0.25 & 1.16 & 0.79 \\
\hline (5-24 July) & Air spec hum. $\left(\mathrm{g} \mathrm{kg}^{-1}\right)$ & 3.61 & +0.47 & 0.56 & 0.83 \\
\hline & Wind speed $\left(\mathrm{m} \mathrm{s}^{-1}\right)$ & 5.643 & -0.87 & 1.99 & 0.55 \\
\hline & Wind direction $\left(^{\circ}\right)$ & 136.2 & +11.72 & 27.52 & 0.40 \\
\hline & Surface albedo (-) & 0.69 & +0.05 & 0.07 & 0.62 \\
\hline
\end{tabular}

837 
LEFEBRE ET AL.: EVALUATION REGIONAL CLIMATE SIMULATION OVER GREENLAND

05.04.07 11:14:48

Table 6: Simulated surface mass balance components in the different model mass balance zones for the reference experiment and the constant 0.8 albedo sensitivity experiment. The absolute mass balance terms are expressed in mmWE. Negative numbers indiquate mass losses. Net melt is the amount of melt adjusted for retention of meltwater inside the snow pack and eventually refreezing. The relative changes are calculated as $[(2)-(1)] /(1)$ with (1) the reference figures and (2) the constant 0.8 albedo results.

\begin{tabular}{|c|c|c|c|c|}
\hline Area & Variable & $\begin{array}{l}\text { Reference } \\
\text { experiment }\end{array}$ & $\begin{array}{l}\text { Albedo sens. } \\
\text { experiment }\end{array}$ & $\begin{array}{l}\text { Relative change } \\
(\%)\end{array}$ \\
\hline \multirow[t]{5}{*}{ Ablation zone } & Mass balance change & -703.6 & -109.6 & -84.42 \\
\hline & Net melt & -958.4 & -365.1 & -62.91 \\
\hline & Sublimation & -26.7 & -22.8 & -14.61 \\
\hline & Rainfall & 112.9 & 106.7 & -5.49 \\
\hline & Snowfall & 168.6 & 171.6 & -1.78 \\
\hline \multirow[t]{5}{*}{ Percolation zone } & Mass balance change & 272.4 & 270.9 & -0.55 \\
\hline & Net melt & -5.0 & -4.5 & -10.00 \\
\hline & Sublimation & -24.9 & -22.4 & -10.04 \\
\hline & Rainfall & 21.7 & 20.9 & -3.69 \\
\hline & Snowfall & 280.6 & 276.9 & -1.32 \\
\hline \multirow[t]{5}{*}{ Dry snow zone } & Mass balance change & 130.12 & 127.22 & -2.23 \\
\hline & Net melt & 0.00 & 0.00 & 0.00 \\
\hline & Sublimation & -10.00 & -9.60 & -4.00 \\
\hline & Rainfall & 1.72 & 1.68 & -2.33 \\
\hline & Snowfall & 138.40 & 135.10 & -2.38 \\
\hline \multirow[t]{5}{*}{ Whole ice sheet } & Mass balance change & 121.5 & 176.1 & 44.94 \\
\hline & Net melt & -93.5 & -37.0 & -60.43 \\
\hline & Sublimation & -19.2 & -17.2 & -10.42 \\
\hline & Rainfall & 22.2 & 21.2 & -4.50 \\
\hline & Snowfall & 212.0 & 209.1 & -1.37 \\
\hline
\end{tabular}

846 
LEFEBRE ET AL.: EVALUATION REGIONAL CLIMATE SIMULATION OVER GREENLAND

05.04.07 11:14:48

Table 7: Statistics at AWS-Klinck and Kangerlussuaq during the summer of 1991 based on 6hourly values. The large MAR surface pressure bias and rmse at Kangerlussuaq is caused by the $855290 \mathrm{~m}$ difference in surface height (Table 2).

\begin{tabular}{|l|l|r|r|r|r|}
\hline Station & Variable & $\begin{array}{l}\text { Obs } \\
\text { mean }\end{array}$ & $\begin{array}{l}\text { MAR } \\
\text { bias }\end{array}$ & $\begin{array}{l}\text { MAR } \\
\text { rmse }\end{array}$ & $\begin{array}{l}\text { MAR } \\
\text { corr }\end{array}$ \\
\hline AWS-Klinck & Air temperature $\left({ }^{\circ} \mathrm{C}\right)$ & -15.66 & -3.12 & 5.12 & 0.87 \\
$\left(1^{\text {st }}\right.$ May $\leftrightarrow$ & Wind speed $\left(\mathrm{m} \mathrm{s}^{-1}\right)$ & 4.08 & +1.8 & 2.64 & 0.72 \\
$31^{\text {st }}$ August $)$ & Wind direction $\left({ }^{\circ}\right)$ & 164.8 & +12.87 & 55.73 & 0.62 \\
& Surface pressure $(\mathrm{hPa})$ & 683.10 & +0.91 & 1.98 & 0.98 \\
\hline Kangerlussuaq & Air temperature $\left({ }^{\circ} \mathrm{C}\right)$ & 7.52 & -4.74 & 7.08 & 0.78 \\
$\left(1^{\text {st }}\right.$ May $\leftrightarrow$ & Relative humidity $(\%)$ & 65.13 & +11.06 & 23.80 & 0.30 \\
$31^{\text {st }}$ August $)$ & Wind speed $\left(\mathrm{m} \mathrm{s}^{-1}\right)$ & 3.64 & -0.82 & 2.27 & 0.19 \\
& Surface pressure $(\mathrm{hPa})$ & 1008.0 & -40.48 & 40.36 & 0.98 \\
\hline
\end{tabular}

